\title{
Evaluation of Oral Health-Related Quality of Life Among
} Dentistry Students

\section{Diş Hekimliği Öğrencilerinde Ağız Sağı̆̆ı ile Yaşam Kalitesi Arasındaki Iliş̧kinin Değerlendirilmesi}

\author{
Gülbahar Ustaoğlu ${ }^{1 *}$, Mustafa Hayati Atala ${ }^{2}$, Kerem Çağlar Gümüş ${ }^{1}$ \\ ${ }^{1}$ Bolu Abant İzet Baysal Üniversitesi, Periodontoloji Anabilim Dal, Bolu, Türkiye \\ ${ }^{2}$ Bolu Abant İzet Baysal Üniversitesi, Protetik Diş Tedavisi Anabilim Dah, Bolu, Türkiye
}

\begin{abstract}
Objective: Oral health-related quality of life (OHRQoL) is an individual's self-perception of how personal oral health affects one's quality of life and general health. This local study aimed to enlighten the relationship between self-rated oral health, oral health-related quality of life, and oral health self-care behaviors among dental university students.

Materials and Methods: A questionnaire was mailed to all participants $(n=380)$, including the Turkish version of 14-item OHIP concerning self-reported oral problems, and oral hygiene habits. The responses to OHIP-14 were chosen among multiple choices, each one response scoring between 0 and 4 points. Self-reported oral problems like decayed teeth, the need for extractions, bleeding gums, dental calculus, malocclusions were evaluated according to their presence or absence. Students were also asked to state daily oral care habits such as usage of dental floss or interdental brush.

Results: The highest mean values found in the study, were related to physical pain and psychological discomfort domains of OHIP-14 with the mean values ranging from 1.19 to 0.93 . Tooth decay $(46.8 \%)$ and dental calculus $(37.8 \%)$ were the most prevalent selfreported dental problems followed by malocclusion $(32.1 \%)$, and need for extractions for several reasons $(23.1 \%)$.

Conclusion: The results of our study showed that dental students were highly knowledgeable and aware about oral care in proportion to the duration of training. Effective dental practice education also increases the awareness of oral health habits of dental students and affects the quality of life positively.
\end{abstract}

Key Words: Awareness, dental students, education, oral health, quality of life

\section{ÖZET}

Amaç: Ağız sağlığı için yaşam kalitesi, bireyin kişisel ağız sağlığının yaşam kalitesini ve genel sağlığı nasıl etkilediğine dair kendi algısıdır. Bu yerel çalışmanın amac1, diş hekimliği öğrencilerinde, ağız sağlığ1 ile ilişkili yaşam kalitesi, kendileri tarafından algılanan ağız sağlığ1 ve ağız sağlı̆̆1 davranışları arasındaki ilişkiyi aydınlatmaktır.

Gereç ve Yöntem: Tüm katılımcılara $(n=380) \quad 14$ maddelik OHIP Türkçe versiyonu, kendileri tarafından bildirilen oral sorunlar ve ağız hijyeni alışkanlıklarını içeren anket soruları mail yoluyla gönderilmiștir. OHIP 14 soruları, farklı yanıt seçenekleri ile 0 - 4 puan arasında skorlanarak, cevaplandı. Kendileri tarafından bildirilen, çürük diş, çekim gereksinim varlığ1, diş eti kanamas1, diş taşı, maloklüzyon gibi oral problemler var/ yok şeklindeki cevaplara göre değerlendirildi. Öğrencilerden ayrıca diş ipi veya interdental firça kullanıp kullanmadıklarını belirtmeleri istenmiştir.

Bulgular: Çalışmada bulunan en yüksek OHIP-14 ortalama değerleri, 1.19 'dan 0.93 'e kadar olan ortalama değerler ile fiziksel ağrı ve psikolojik rahatsızlık alanlarında bulundu. Kendileri tarafından bildirilen diş problemleri arasında en sik görülen diş çürügü (\% 46.8) ve diş taşı ( $\% 37.8)$ olup, bunu sırasıyla maloklüzyon ( $\%$ 32.1) ve çeşitli nedenlerle ekstraksiyona gereksinim (\% 23.1) takip etmiştir.

Sonuç: Çalışmamızın sonuçları, diş hekimliği öğrencilerinin ağız bakımı ile ilgili bilgi ve farkındalık düzeylerinin, eğitim süreleri ile doğru orant1lı olarak arttığını göstermiștir. Etkin diș hekimliği eğitimi, diș hekimliği öğrencilerinin ağız sağlı̆̆ alışkanlıklarına ilişkin farkındalığ1 arttırmakta ve yaşam kalitesini olumlu yönde etkilemektedir.

Anahtar Kelimeler: Farkındalık, diş hekimliği öğrencileri, eğitim, ağız sağlığı, yaşam kalitesi

*Sorumlu Yazar: Dr. Gülbahar Ustaoğlu, Bolu Abant Izzet Baysal University, Faculty of Dentistry, Department of Periodontology, 14000 , Gölkoy, Bolu, Turkey

E-mail: gulbaharustaoglu@hotmail.com, Phone: 90 (544) 56751 66, Fax: 90 (374) 2540066 Geliş Tarihi: 07.01.2019, Kabul Tarihi: 15.11.2019

ORCID ID: Gülbahar Ustaoğlu: 0000-0002-4205-861X, Mustafa Hayati Atala: 0000-0003-1194-0703, Kerem Cağlar Gümüș: 0000-0002-3028- 


\section{Introduction}

The concept of health should be explained not only in terms of having no illness but as a state of full well-being as for physiological, psychological, and social aspects. Similar description can be also made for oral health. Oral health affects people psychologically and physiologically; for example, it affects their pleasures for living, speaking, chewing ability and potential for socialization (1).

Dental students were known to be vulnerable to stress and psychological problems under considerable academic pressure and demands of their education $(2,3)$. In the first three years, dental students should master laboratory practice that needs much time and manual skills. In the last two years of their training, students treat their patients and are responsible for their care. Also, they must fulfill their clinical requirements and pass tests (4). Meanwhile starting to live away from their parents for the first time in their lives may affect their life style, behaviors, and health (5). Dentistry students are anticipated to improve their oral care behavior and habits during university education. (6). Oral health-related quality of life is an individual's self-perception about the impact of personal oral health on the quality of life and general health. The short-form OHRQoL-14 was developed as a modified version of OHIP and is reported to have excellent reliability, validity, and precision (7). Oral Health Impact Profile-14 (OHIP-14) is a questionnaire system that evaluates this perception by using two questions for the detection of functional limitation, physical pain, psychological discomfort, physical, psychological and social dimensions of disability and handicap dimension. It has been concluded that the higher the total score, the more severe the problem and the lower the quality of life (7). Although several studies drawing attention to these questionnaire items have been investigated in different countries and cultures (811), limited number of studies have investigated quality of life of dental students $(12,13)$.

The aim of our study was to enlighten the relationship between self-rated oral health and OHRQoL, and also investigate its elaboration within the frame of the dental education system.

\section{Materials and Methods}

The study was performed among dental students ( $n=380)$ of the Faculty of Dentistry, Bolu Abant İzzet Baysal University, Turkey. Ethics Committee approval in Human Research of Bolu Abant İzzet Baysal University was obtained (number: 2018/67) and the study was performed in compliance with the Declaration of Helsinki. Based on a previous study (12), statistical power of the study was calculated, and its sample size was determined using a statistical software (G*Power 3.1 software; Heinrich Heine University, Dusseldorf, Germany). A consent form was obtained from all participants. A questionnaire was mailed to all participants including the Turkish version of 14-item OHIP (14) concerning selfreported oral problems and oral hygiene habits. Email method was chosen to prevent wasting paper. The responses to 14 items of OHIP- (7) were selected from multiple choices, each one scored between 0 to 4 points as shown in Table 1 . The total points for each item give the overall score ranging from 0 to 56 points. A high score means more significantly perceived oral health problems. The self-reported oral problems like decayed teeth, the need for extractions, bleeding gums, dental calculus, malocclusions were evaluated according to their presence or absence.

Oral hygiene habits were evaluated by asking about the daily frequency of tooth-brushing, with the possible answers being 1,2 , or $\geq 3$ times. Students were also asked to state whether they used dental floss or interdental brush and the probable reason for the last visit to the dentist. The reasons for the visit was divided into three groups, as follows: check-up, prevention, and treatment.

Statistical Analysis: Data was analyzed with IBM SPSS Statistics Version 23 software package. Normal distribution conformity was examined with Shapiro Wilk. Mann Whitney U and Kruskal Wallis test were used for comparison of data with non-normally distribution. The chi-square test was used to compare qualitative data. The Bonferroni correction was applied to adjust for multiple comparisons in the analysis. Qualitative data were presented as the percentage when the non-normal distributions were presented as median (min-max). $\mathrm{p}<0.05$ was considered as statistically significant.

\section{Results}

The frequency of reported impact on each item of the OHIP-14 questions is presented in Table 1. The highest mean values found in the study were related to the domains of physical pain and psychological discomfort with the median values ranging from 1.19 to 0.93 points by turns (Table 2).

Total median OHIP-14 scores of the first year(median score: 0.6 ) and the $5^{\text {th }}$ year- (median score: $0.4)$ students differed statistically significantly $(\mathrm{p}=0.017)$. 
Table 1. The frequency of reported impact on each item of the OHIP-14 questions

\begin{tabular}{|c|c|c|c|c|c|}
\hline Item & $\begin{array}{c}\text { Answers } \\
0 \\
(\mathrm{Never}) \\
\mathrm{N}(\%)\end{array}$ & $\begin{array}{c}1 \\
\text { (Hardly ever) } \\
\mathrm{N}(\%)\end{array}$ & $\begin{array}{c}2 \\
\text { (Occasionally) } \\
\mathrm{N}(\%)\end{array}$ & $\begin{array}{l}3 \\
\text { (Fairly often) } \\
\mathrm{N}(\%)\end{array}$ & $\begin{array}{c}4 \\
\text { (Very often) } \\
\mathrm{N}(\%)\end{array}$ \\
\hline $\begin{array}{l}\text { 1. Have you had trouble } \\
\text { pronouncing any words because of } \\
\text { problems with your teeth or mouth? }\end{array}$ & $253(66.6)$ & $83(21.8)$ & $36(9.5)$ & $8(2.1)$ & $0(0)$ \\
\hline $\begin{array}{l}\text { 2. Have you felt that your sense of } \\
\text { taste has worsened because of } \\
\text { problems with your teeth or mouth? }\end{array}$ & 261(68.7) & $86(22.6)$ & $26(6.8)$ & $7(1.8)$ & $0(0)$ \\
\hline $\begin{array}{l}\text { 3. Have you had painful aching in } \\
\text { your mouth? }\end{array}$ & $45(11.8)$ & $175(46.1)$ & $152(40)$ & $8(2.1)$ & $0(0)$ \\
\hline $\begin{array}{l}\text { 4. Have you found it uncomfortable } \\
\text { to eat any foods because of problems } \\
\text { with your teeth or mouth? }\end{array}$ & $122(32.2)$ & $133(35.1)$ & $104(27.4)$ & $19(5)$ & $1(0.3)$ \\
\hline $\begin{array}{l}\text { 5. Have you been self-conscious } \\
\text { because of your teeth or mouth? }\end{array}$ & $161(42.5)$ & $108(28.5)$ & $75(19.8)$ & $30(7.9)$ & $5(1.3)$ \\
\hline $\begin{array}{l}\text { 6. Have you felt tense because of } \\
\text { problems with your teeth or } \\
\text { mouth? }\end{array}$ & $151(40.1)$ & $137(36.3)$ & $70(18.6)$ & $17(4.5)$ & $2(0.5)$ \\
\hline $\begin{array}{l}\text { 7. Has been your diet been } \\
\text { unsatisfactory because of problems } \\
\text { with your teeth of mouth? }\end{array}$ & $218(57.5)$ & $116(30.6)$ & $37(9.8)$ & $8(2.1)$ & $0(0)$ \\
\hline $\begin{array}{l}\text { 8. Have you had to interrupt meals } \\
\text { because of problems with }\end{array}$ & & & & & \\
\hline your teeth or mouth? & $227(59.9)$ & $110(29)$ & $41(10.8)$ & $1(0.3)$ & $0(0)$ \\
\hline $\begin{array}{l}\text { 9. Have you found it difficult to relax } \\
\text { because of problems with }\end{array}$ & & & & & \\
\hline your teeth or mouth? & $121(31.9)$ & $159(42)$ & $79(20.8)$ & $19(5)$ & $1(0.3)$ \\
\hline $\begin{array}{l}\text { 10. Have you been a bit embarrassed } \\
\text { because of problems with your teeth } \\
\text { or mouth? }\end{array}$ & $210(55.4)$ & $98(25.9)$ & $55(14.5)$ & $16(4.2)$ & $0(0)$ \\
\hline $\begin{array}{l}\text { 11. Have you been a bit irritable with } \\
\text { other people because of }\end{array}$ & & & & & \\
\hline problems with your teeth or mouth? & $245(64.5)$ & $98(25.8)$ & $31(8.2)$ & $6(1.6)$ & $0(0)$ \\
\hline $\begin{array}{l}\text { 12. Have you had difficulty doing } \\
\text { your usual jobs because of problems } \\
\text { with your teeth or mouth? }\end{array}$ & $253(66.8)$ & $98(25.9)$ & $25(6.6)$ & $3(0.8)$ & $0(0)$ \\
\hline $\begin{array}{l}\text { 13. Have you felt that life in general } \\
\text { was less satisfying because of } \\
\text { problems with your teeth or mouth? }\end{array}$ & $189(49.9)$ & $130(34.3)$ & $46(12.1)$ & $12(3.2)$ & $2(0.5)$ \\
\hline $\begin{array}{l}\text { 14. Have you been totally unable to } \\
\text { function because of problems with } \\
\text { your teeth or mouth? }\end{array}$ & $344(91)$ & $25(6.6)$ & $9(2.4)$ & $0(0)$ & $0(0)$ \\
\hline
\end{tabular}

$\mathrm{N}$ : Number of subjects 
Table 2. Prevalence of reported impact of oral conditions on quality of life and OHIP-14 scores among dental students

\begin{tabular}{lccccc}
\hline OHIP-14 subscales & Mean & SD & Median & Minimum & Maximum \\
\hline Functional limitation & 0.44 & 0.60 & 0.00 & 0 & 3 \\
OHIP 1 & 0.47 & 0.75 & 0 & 0 & 3 \\
OHIP 2 & 0.42 & 0.70 & 0 & 0 & 3 \\
Physical pain & 1.19 & 0.68 & 1.00 & 0 & 3 \\
OHIP 3 & 1.32 & 0.71 & 1 & 0 & 3 \\
OHIP 4 & 1.06 & 0.91 & 1 & 0 & 4 \\
Psychological discomfort & 0.93 & 0.85 & 0.50 & 0 & 4 \\
OHIP 5 & 0.97 & 1.03 & 1 & 0 & 4 \\
OHIP 6 & 0.89 & 0.90 & 1 & 0 & 4 \\
Physical disability & 0.54 & 0.66 & 0.50 & 0 & 3 \\
OHIP 7 & 0.56 & 0.75 & 0 & 0 & 3 \\
OHIP 8 & 0.51 & 0.70 & 0 & 0 & 3 \\
Psychological disability & 0.84 & 0.79 & 0.50 & 0 & 4 \\
OHIP 9 & 1.00 & 0.87 & 1 & 0 & 4 \\
OHIP 10 & 0.68 & 0.87 & 0 & 0 & 3 \\
Social disability & 0.44 & 0.59 & 0.00 & 0 & 3 \\
OHIP 11 & 0.47 & 0.71 & 0 & 0 & 3 \\
OHIP 12 & 0.41 & 0.65 & 0 & 0 & 3 \\
Social handicap & 0.41 & 0.51 & 0.50 & 0 & 3 \\
OHIP 13 & 0.70 & 0.84 & 1 & 0 & 4 \\
OHIP 14 & 0.11 & 0.39 & 0 & 0 & 2 \\
Mean total score & 0.68 & 0.50 & 0.57 & 0 & 3 \\
\hline SD Standan Den & \\
\hline
\end{tabular}

SD: Standard Deviation

items differed statistically significantly according to years of training concerning the domains of 'physical and 'psychological discomfort' $(\mathrm{p}<0.05)$. The total OHIP- 14 median values were $0.6,0.5,0.8,0.5$ and 0.4 points respectively from the first to fifth years of education. OHIP- 14 scores of $3^{\text {rd }}$ and $5^{\text {th }}$ yearsstudents differed (Table 3).

According to the results, tooth decay $(46.8 \%)$ and dental calculus $(37.8 \%)$, were most frequently reported conditions followed by malocclusion $(32.1 \%)$, and need for extractions for several reasons (23.1\%). The incidence of tooth decay and dental calculus has decreased at a statistically significant rate from the first year to the last year (Table 4). According to correlation analysis, there was a significant difference between the mean OHIP-14 scores with self-rated problems of decayed teeth, bleeding gums, dental calculus, and malocclusions When comparing tooth brushing habits for dental students, the vast majority seemed to brush their teeth three or more times a day (Table 5).

\section{Discussion}

Studies have revealed that young and middle-aged adults report worse oral health problems than older adults, although oral problems tend to increase with age $(15,16)$. Several studies on OHRQoL in young adult populations, including young university students concluded that self-rated oral health, oral pain, and malocclusion were directly associated with the OHRQoL $(8,10,17)$.

In the literature, oral health habits of dentistry students have been researched by items of different questionnaire $(12,13,18)$. Kawamura et al. (18) used the 20-item questionnaire (Hiroshima UniversityDental Behavioural Inventory) to assess cultural differences of self-reported oral health behavior in Japanese and Finnish dentistry students. They concluded that these oral health behaviors might differ between the two countries which might be related to economic factors, different health education systems and cultures (18). In another study, Uraz et al. (19) used Short Form Health Survey (SF36) to evaluate the physical and mental health of dental students, and they found that physical 
Table 3. Summary of mean OHIP-14 scores according to the year of the course

\begin{tabular}{lcccccc}
\hline & $\begin{array}{c}\text { First year } \\
\mathrm{n}=83\end{array}$ & $\begin{array}{c}\text { Second year } \\
\mathrm{n}=78\end{array}$ & $\begin{array}{c}\text { Third year } \\
\text { Median }\end{array}$ & $\begin{array}{c}\text { Median } \\
\mathrm{n}=80 \text { Median }\end{array}$ & $\begin{array}{c}\text { Median } \\
\mathrm{n}=87\end{array}$ & $\begin{array}{c}\text { Fifth year } \\
\mathrm{n}=52\end{array}$ \\
& $0(0-1.5)$ & $0.3(0-3)$ & $0.5(0-2)$ & $0(0-2)$ & $0(0-3)$ & 0.129 \\
Functional limitation & $1(0-3) \mathrm{ab}$ & $1(0-3) \mathrm{ab}$ & $1.5(0-2.5) \mathrm{a}$ & $1(0-3) \mathrm{ab}$ & $1(0-3) \mathrm{b}$ & 0.013 \\
Physical pain & $0.5(0-3.5) \mathrm{ab}$ & $0.8(0-4) \mathrm{ab}$ & $1(0-3.5) \mathrm{a}$ & $0.5(0-3) \mathrm{ab}$ & $0.5(0-2) \mathrm{b}$ & 0.042 \\
Psychological discomfort & $0.5-2.5)$ & $0.5(0-2.5)$ & $0.5(0-2.5)$ & $0.5(0-2.5)$ & $0.3(0-3)$ & 0.203 \\
Physical disability & $0(0-5)$ & $0.5(0-3)$ & 0.057 \\
Psychological disability & $1(0-3)$ & $0.5(0-3.5)$ & $1(0-3)$ & $0.5(0-3)$ & $0.5(0)$ & 0.417 \\
Social disability & $0.5(0-2.5)$ & $0.5(0-2)$ & $0.3(0-2)$ & $0(0-3)$ & $0(0-2)$ & 0.071 \\
Handicap & $0(0-2)$ & $0.5(0-2)$ & $0.5(0-2)$ & $0(0-2.5)$ & $0(0-2.5)$ & 0.071 \\
Total & $0.6(0-2.3) \mathrm{ab}$ & $0.5(0-1.9) \mathrm{ab}$ & $0.8(0-1.9) \mathrm{a}$ & $0.5(0-2) \mathrm{ab}$ & $0.4(0-2.6) \mathrm{b}$ & 0.017 \\
\hline
\end{tabular}

Notes: If the any group mean carry superscript different letters from the other group mean. it indicates that the difference between them is statistically significant difference

Table 4. Self-reported oral problems among the respondents

\begin{tabular}{lcccccc}
\hline $\begin{array}{l}\text { Year of } \\
\text { the course }\end{array}$ & $\begin{array}{c}\text { Self-reported } \\
\text { tooth decay } \\
\mathrm{N}(\%)\end{array}$ & $\begin{array}{c}\text { Need for } \\
\text { extractions } \\
\mathrm{N}(\%)\end{array}$ & $\begin{array}{c}\text { Bleeding gums } \\
\mathrm{N}(\%)\end{array}$ & $\begin{array}{c}\text { Dental } \\
\text { calculus } \\
\mathrm{N}(\%)\end{array}$ & $\begin{array}{c}\text { Malocclusions } \\
\mathrm{N}(\%)\end{array}$ & $\begin{array}{c}\text { Interdental } \\
\text { cleaning } \\
\mathrm{N}(\%)\end{array}$ \\
\hline 1 & $31(37.3)$ & $11(13.3)^{*}$ & $23(27.7)^{*}$ & $34(41)$ & $21(25.3)$ & $30(36.1)^{*}$ \\
2 & $38(48.7)$ & $12(15.4)$ & $9(11.5)$ & $36(46.2)$ & $24(30.8)$ & $34(43.6)$ \\
3 & $43(53.8)$ & $22(27.8)$ & $19(23.8)^{*}$ & $38(47.5)$ & $34(42.5)$ & $51(63.8)$ \\
4 & $49(56.3)$ & $30(34.5)^{*}$ & $2(2.3)^{*}$ & $26(29.9)$ & $25(28.7)$ & $57(65.5)^{*}$ \\
5 & $17(32.7)^{*}$ & $13(25)$ & $3(5.8)$ & $10(19.2)^{*}$ & $18(34.6)$ & $33(63.5)$ \\
Total & $178(46.8)$ & $88(23.1)$ & $56(14.7)$ & $144(37.8)$ & $122(32.1)$ & $205(53.9)$ \\
\hline
\end{tabular}

$\mathrm{N}$ : Number of subjects

functioning (PH) and role-physical (RP) items showed a statistically significant difference according to education years of dental students.

Although OHIP was intended to offer comprehensive data about the perception of well-being, in our study, we used OHIP- 14 for which reliability, validity, accuracy, and precision also has been established (7). It is the most comprehensive measure of oral health and subjective tool that can be used in oral health surveys, clinical trials and to examine the results of clinical procedures $(20,21)$. Also in our study questions were responded during face-to- face interviews and we used e-mail method to prevent wasting paper and to reach all students as in the case with Yamane-Takeuchi's study (8).

In this study, the impact of oral health status on daily activities has been comparatively investigated locally in Turkish local dental students, and we found that oral health of students had a low impact of on their quality of life. These results show similarities with Acharya's and Gonzales-Sullcahuamán's crosssectional studies $(12,13)$. These findings can be explained with younger age of our study group, receiving education about dental and oral health and ease of access to dental treatments. Physical pain and psychological discomfort subscale scores were more frequently higher when compared with scores of other subscales of OHIP-14 and affect the quality of life negatively. Gonzales-Sullcahuamán et al. (13) found that "self-esteem of the individuals decreased because of oral and dental problems" and "severe pain in mouth" was the most frequently reported complaint that adversely effected OHRQoL. Also in another research, Acharya et al. (12) concluded that OHIP-14 items of physical pain and psychological discomfort showed the highest mean values, which were similar to our results In our research, the subscales that most seen to have an impact on OHRQoL were physical pain and psychological discomfort. According to the answers to OHIP 14 items, there was a significant difference between the third and fifth-year students. Students are generally encouraged to aware and value their oral health care, so they have a high level of concern about problematic dental appearance of their teeth and mouth, which can explain their psychological discomfort. 
Table 5. Oral health-related quality of life and its relationship with self-reported oral problems

\begin{tabular}{lcccc}
\hline $\begin{array}{l}\text { Self-reported oral } \\
\text { health status }\end{array}$ & Prevalence & Number & $\begin{array}{c}\text { Median (SD) of } \\
\text { OHIP-14 scores }\end{array}$ & Differences P-value \\
\hline Reason for last & Checkup & 197 & $0.5(0-2.6) \mathrm{a}$ & $<0.001$ \\
visit to dentist & Prevention & 26 & $0.5(0.1-2) \mathrm{ab}$ & \\
& Treatment & 154 & $0.8(0-2.3) \mathrm{b}$ & $<0.001$ \\
Decayed & Present & 178 & $0.7(0-2.3)$ & \multirow{2}{*}{0.854} \\
teeth & Absent & 202 & $0.5(0-2.6)$ & \\
Need for & Present & 88 & $0.5(0-2.3)$ & 0.003 \\
extractions & Absent & 291 & $0.6(0-2.6)$ & \\
Bleeding gums & Present & 56 & $0.8(0.1-2.3)$ & 0.020 \\
Dental calculus & Absent & 323 & $0.5(0-2.6)$ & 0.002 \\
Malocclusions & Aresent & 144 & $0.7(0-1.9)$ & \\
& Absent & 236 & $0.5(0-2.6)$ & 0.060 \\
Tresent & 122 & $0.8(0-2.6)$ & \\
frequency & Absent & 258 & $0.5(0-2.3)$ & 0.077 \\
& One time & 58 & $0.8(0.1-2.3)$ & \\
Interdental & Morning/evening & 54 & $0.5(0-2.6)$ & \\
cleaning & Three times & 267 & $0.8(0-1.4)$ & \\
\hline
\end{tabular}

SD: Standard Deviation

When we evaluated self-reported oral problems, a prominent increase in oral problems were noted between the first and fifth- year students. This increase shows that awareness of students about oral health and oral hygiene habits raise during dentistry education. Similar to our study, Rong et al. (22) and Kawamura et al. (18) concluded that dental students had improved their oral health care habits and behavior from their first -to the final years of their education.

According to self-reported questionnaires about oral health, tooth decay (46.8\%) and dental calculus $(37.8 \%)$ were the most seen problems in Turkish students. This finding may be related to socioeconomic status and eating habits of Turkish students in pre-university life. Additionally, some problems such as bleeding gum and dental calculus accumulation rates start to decrease in the third grade. This situation may be related to the clinical courses associated with dental education in Turkey starting in the third grade when students are beginning to learn how to brush correctly and clean up the interfaces. As known that there is an inverse relationship between dental calculus accumulation, bleeding gum and interdental cleaning according to time-dependent change. On the contrary in Acharya's study (12), dental calculus $(32.3 \%)$ and malocclusion $(25.2 \%)$ were the most seen problems followed by tooth decay $(18.7 \%)$ and need for extractions for several reasons
(14.4\%). In line with the findings of Acharya et al. (12), Self-reported oral problems exerted strong effects on the perceived OHRQoL of the students. On the other hand, the OHIP-14 scores of students who visited the dentists for regular control and treatment showed a significant difference compared to baseline. This result showed that regular visits to dentists for oral check-up 1 has prevented oral problems and increased awareness about oral health.

Limitations: In our study, we did not evaluate the gender parameter according to the OHIP-14 results. Gender is a very crucial point in oral health-related quality of life studies. Also it was not possible to investigate socioeconomic status in this study, which was another limitation. This study was a crosssectional design, and to develop a better model, conduction of a prospective cohort study and an interventional study would be required.

The results of our study showed that the knowledge and awareness level of dentistry students about oral care was high in proportion to the duration of training. Effective education on dental practice also increases the awareness of oral health habits of dental students and affects the quality of life positively. 


\section{References}

1. Sheiham A. Oral health, general health and quality of life. Bull World Health Organ 2005; 83(9): 644.

2. Tosevski DL, Milovancevic MP, Gajic SD. Personality and psychopathology of university students. Curr Opin Psychiatry 2010; 23(1): 48-52.

3. Stormon N, Ford PJ, Eley DS. Exploring personality in Australian dentistry students: Implications for coping with a challenging degree. Eur J Dent Educ 2019; 23(1): 8-13.

4. Schmitter M, Liedl M, Beck J, Rammelsberg P. Chronic stress in medical and dental education. Med Teach 2008; 30(1): 97-99.

5. Kojima A, Ekuni D, Mizutani S, Furuta M, Irie K, Azuma $\mathrm{T}$, et al. Relationships between self-rated oral health, subjective symptoms, oral health behavior and clinical conditions in Japanese university students: a cross-sectional survey at Okayama University. BMC Oral Health 2013; 13 : 62.

6. Messer LB, Calache H. Oral health attitudes and behaviours of final-year dental students. Eur J Dent Educ 2012; 16(3): 144-155.

7. Slade GD. Derivation and validation of a shortform oral health impact profile. Community Dent Oral Epidemiol 1997; 25(4): 284-290.

8. Yamane-Takeuchi M, Ekuni D, Mizutani S, Kataoka K, Taniguchi-Tabata A, Azuma T, et al. Associations among oral health-related quality of life, subjective symptoms, clinical status, and selfrated oral health in Japanese university students: a cross-sectional study. BMC Oral Health 2016; 16(1): 127.

9. Montero J, Yarte JM, Bravo M, Lopez-Valverde A. Oral health-related quality of life of a consecutive sample of Spanish dental patients. Med Oral Patol Oral Cir Bucal 2011; 16(6): 810815.

10. Drachev SN, Brenn T, Trovik TA. Oral Health Related Quality of Life in Young Adults: A Survey of Russian Undergraduate Students. Int J Environ Res Public Health 2018; 15(4): 719-731.

11. Isiekwe GI, Onigbogi OO, Olatosi OO, Sofola OO. Oral Health Quality of Life in a Nigerian University Undergraduate Population. J West Afr Coll Surg 2014; 4(1): 54-74.
12. Acharya S, Sangam DK. Oral health-related quality of life and its relationship with health locus of control among Indian dental university students. Eur J Dent Educ 2008; 12(4): 208-212.

13. Gonzales-Sullcahuaman JA, Ferreira FM, de Menezes JV, Paiva SM, Fraiz FC. Oral healthrelated quality of life among Brazilian dental students. Acta Odontol Latinoam 2013; 26(2): 7683.

14. Başol ME KL, Yılmaz B. Türkçe Ağız Sağlığı Etki Ölçeğinin Geliştirilmesi-OHIP-14-TR. Turkiye Klinikleri J Dental Sci 2014; 20(2): 85-92.

15. Dahl KE, Wang NJ, Skau I, Ohrn K. Oral healthrelated quality of life and associated factors in Norwegian adults. Acta Odontol Scand 2011; 69(4): 208-214.

16. Sanders AE, Slade GD, Lim S, Reisine ST. Impact of oral disease on quality of life in the US and Australian populations. Community Dent Oral Epidemiol 2009; 37(2): 171-181.

17. Saho H, Ekuni D. Structural equation modeling to detect predictors of oral health-related quality of life among Japanese university students: a prospective cohort study. Qual Life Res 2019;28(12): 3213-3224.

18. Kawamura M, Honkala E, Widstrom E, Komabayashi T. Cross-cultural differences of selfreported oral health behaviour in Japanese and Finnish dental students. Int Dent J 2000; 50(1): 46-50.

19. Uraz A, Tocak YS, Yozgatligil C, Cetiner S, Bal B. Psychological well-being, health, and stress sources in Turkish dental students. J Dent Educ 2013; 77(10): 1345-1355.

20. John MT, Patrick DL, Slade GD. The German version of the Oral Health Impact Profile-translation and psychometric properties. Eur J Oral Sci 2002; 110(6): 425-433.

21. John MT, Hujoel P, Miglioretti DL, LeResche L, Koepsell TD, Micheelis W. Dimensions of oralhealth-related quality of life. J Dent Res 2004; 83(12): 956-960.

22. Rong WS, Wang WJ, Yip HK. Attitudes of dental and medical students in their first and final years of undergraduate study to oral health behaviour. Eur J Dent Educ 2006; 10(3): 178-84. 